\title{
Functional Characterization of DNase X, a Novel Endonuclease Expressed in Muscle Cells ${ }^{\dagger}$
}

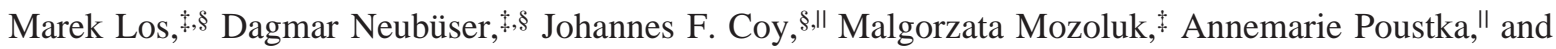 \\ Klaus Schulze-Osthoff*," \\ Department of Immunology and Cell Biology, University of Münster, Münster, and German Cancer Research Center, Division \\ of Molecular Genome Analysis, Heidelberg, Germany
}

Received January 24, 2000; Revised Manuscript Received April 10, 2000

\begin{abstract}
The activation of endonucleases resulting in the degradation of genomic DNA is one of the most characteristic changes in apoptosis. Here, we report the characterization of a novel endonuclease, termed DNase $\mathrm{X}$ due to its $\mathrm{X}$-chromosomal localization. The active nuclease is a $35 \mathrm{kDa}$ protein with $39 \%$ identity to DNase I. When incubated with isolated nuclei, recombinant DNase X was capable of triggering DNA degradation at internucleosomal sites. Similarly to DNase I, the nuclease activity of DNase $X$ was dependent on $\mathrm{Ca}^{2+}$ and $\mathrm{Mg}^{2+}$ and inhibited by $\mathrm{Zn}^{2+}$ ions or chelators of bivalent cations. Overexpression of DNase X caused internucleosomal DNA degradation and induction of cell death associated with increased caspase activation. Despite the presence of two potential caspase cleavage sites, DNase $\mathrm{X}$ was processed neither in vitro nor in vivo by different caspases. Interestingly, after initiation of apoptosis DNase $\mathrm{X}$ was translocated from the cytoplasm to the nuclear compartment and aggregated as a detergent-insoluble complex. Abundant expression of DNase X mRNA was detected in heart and skeletal muscle cells, suggesting that DNase X may be involved in apoptotic or other biological events in muscle tissues.
\end{abstract}

Apoptosis is the innate mechanism of cell clearance in many physiological and pathological processes. Although the signals inducing apoptosis are very different, nuclear condensation, membrane blebbing and formation of apoptotic bodies are morphological features common to all apoptotic cells. Several biochemical changes are associated with these morphological alterations. The two best known biochemical changes are increases in endonuclease and caspase protease activity $(1-5)$. Cleavage of chromatin into oligonucleosomal fragments, which form the characteristic apoptotic DNA ladder, has been documented in numerous cell death models.

In contrast to the key regulators of apoptosis including caspases and anti-apoptotic Bcl-2 proteins, the identity of the enzymes responsible for DNA cleavage is still subject of considerable debate (6). A number of $\mathrm{Ca}^{2+}$ - and $\mathrm{Mg}^{2+}$ dependent endonucleases acting at neutral $\mathrm{pH}$ have been characterized, such as in thymocytes NUC18/cyclophilin A (7), DNase I $(8,9)$, DNase $\gamma(10)$, and a $97 \mathrm{kDa}$ DNase (11). In human myeloid cells, $\mathrm{Mg}^{2+}$-dependent but $\mathrm{Ca}^{2+}$ independent DNases have been described (12). Cationindependent enzymes, such DNase II and L-DNase II, have been implicated as acidic endonucleases that degrade DNA in those forms of apoptosis which are associated with intracellular acidification (13-17). In addition, much atten-

This work was supported in part by grants from the Deutsche Forschungsgemeinschaft, the IZKF of the University of Münster, and the European Union Biomed-2 program.

* To whom correspondence should be addressed. Phone: +49-251835 2936. Fax: +49-251-835 2250. E-mail: kso@uni-muenster.de.

University of Münster.

$\S$ These authors contributed equally to this work.

" German Cancer Research Center. tion has been paid recently to $\mathrm{CAD}^{1}$ (caspase-activated DNase), an enzyme which is stimulated upon caspasemediated cleavage of its inhibitory subunit ICAD/DFF45 $(18-20)$.

There have been also cell death systems in which internucleosomal DNA degradation does obviously not occur (21, 22). Nevertheless, despite the lack of appearance of oligonucleosomal DNA fragmentation, in most cases, chromatin condensation and the formation of high molecular weight DNA fragments of 50 to $>1000 \mathrm{~kb}$ can be observed (23). It has been suggested that some endonucleases may mediate both the high molecular weight DNA fragmentation and the subsequent oligosomal DNA degradation, while there are also evidences that both steps of DNA cleavage are triggered by separate nucleases (6). Apoptosis-inducing factor (AIF), for instance, mediates chromatin condensation and high molecular weight fragmentation, but does not cause the appearance of a classical DNA ladder (24). In addition, Acinus, a recently cloned chromatin condensation factor, induces nuclear pyknosis in the absence of DNase activity (25).

The pathways leading to activation of the different endonucleases in apoptosis are only poorly understood. Important mechanisms include the proteolysis of an inhibitor as in the case of CAD/ICAD (15), or an acidic pH-dependent

${ }^{1}$ Abbreviations: CAD, caspase-activated DNase; DAPI, 4,6-diamidine-2-phenylindole; DEVD-AMC, $N$-acetyl-Asp-Glu-Val-Asp-aminomethylcoumarin; DTT, dithiothreitol; GFP, green fluorescent protein; ICAD, inhibitor of CAD; PARP, poly(ADP-ribose)polymerase; PBS, phosphate-buffered saline; PMSF, phenylmethanesulfonyl fluoride; TBS, Tris-buffered saline; zVAD, benzyloxycarbonyl-Val-Ala-Asp(OMe)fluoro-methylketone. 
posttranslational modification of an inactive precursor as in the case of the $27 \mathrm{kDa}$ L-DNase II, which is derived from the $42 \mathrm{kDa}$ serpin-like leukocyte elastase inhibitor $(20,17)$. $\mathrm{Ca}^{2+}$-sensitive DNases, on the other hand, are stimulated by an increase in cytosolic calcium concentrations, which is observed in various apoptotic models. In addition, alterations in the $\mathrm{pH}$ value may stimulate endonucleases, such as DNase II, which require intracellular acidification to be activated (26). Finally, it is noteworthy that, although internucleosomal DNA fragmentation is a very common event in apoptosis, the tissue distribution of several endonucleases is rather restricted. Human CAD is expressed in a limited number of tissues, including pancreas, spleen, prostate, and ovary, whereas in other tissues, no or only low levels of transcripts can be detected (27). DNase I, a secretable enzyme, is mainly expressed in the parotid and submaxillary glands, pancreas, kidney, and intestinal mucosa, where it, besides apoptotic roles, may exert digestive functions (28). In addition, DNase $\gamma$ and NUC70 are almost exclusively detected in T-lymphocytes and hematopoietic cells, respectively $(10,29)$. These findings suggest that the apoptotic role of individual endonucleases appears to be remarkably context-dependent and specific for certain cell types and tissues.

In the present study, we describe a novel endonuclease, termed DNase X. The nuclease is a $35 \mathrm{kDa}$ enzyme capable of inducing a characteristic DNA ladder and has a 39\% identity to DNase I. Transient overexpression of DNase X led to increased internucleosomal DNA degradation and induction of cell death. Despite the presence of potential caspase cleavage sites, DNase $\mathrm{X}$ was not processed by different caspases. However, during apoptosis, DNase X was translocated from the cytoplasm to the nuclear compartment and aggregated as a detergent-insoluble complex. Northern and Western blot analyses revealed that DNase $\mathrm{X}$ was predominantly expressed in skeletal and heart muscle cells and different tumor cell lines, suggesting that DNase X may be involved in apoptotic or other biological events in muscle tissues.

\section{EXPERIMENTAL PROCEDURES}

Reagents. The broad-range caspase inhibitor zVAD was purchased from Enzyme Systems (Dublin, CA). Staurosporine was obtained from Calbiochem (Bad Soden, Germany) and purified bovine pancreatic DNase I from Sigma (Deisenhofen, Germany). Recombinant PARP was kindly provided by Dr. G. deMurcia (Strasbourg, France). The following antibodies were used: mouse anti-CD95 IgG (BioCheck, Münster, Germany), mouse anti-histidine tag IgG (Dianova, Hamburg, Germany), rabbit anti-PARP (Roche Diagnostics, Mannheim, Germany), and mouse anti-GFP (Clontech, Heidelberg, Germany). An anti-DNase X antiserum was generated by immunizing rabbits with affinity-purified recombinant DNase X.

Bacterial Expression and Purification of DNase X. Recombinant DNase X was expressed in Escherichia coli as a histidine fusion protein. The full-length cDNA of DNase $\mathrm{X}$ was cut with $\mathrm{Bam} \mathrm{H} 1$ and ligated with T4-DNA ligase into the unique Bam $\mathrm{H} 1$ site of the expression vector pQE-8 (Qiagen, Hilden, Germany). For expression, bacteria were transformed and grown in LB medium with $100 \mu \mathrm{g} / \mathrm{mL}$ ampicillin and $25 \mu \mathrm{g} / \mathrm{mL}$ kanamycin and induced with
$60 \mu \mathrm{M}$ isopropylthiogalactoside. After $4 \mathrm{~h}$, bacteria were lysed by sonification in $50 \mathrm{mM}$ Tris- $\mathrm{HCl}, \mathrm{pH} 7.6,150 \mathrm{mM}$ $\mathrm{NaCl}$ containing pepstatin $\mathrm{A}$, aprotinin, and leupeptin (each $2 \mu \mathrm{g} / \mathrm{mL}$ ). Following centrifugation, the pellet containing inclusion bodies was extracted with $0.5 \%$ Triton $\mathrm{X}-100$ in $20 \mathrm{mM}$ Tris-HCl, pH 7.5, $1 \mathrm{mM}$ EDTA, and 5\% sucrose. The proteins were dialyzed against $50 \mathrm{mM}$ sodium phosphate, $\mathrm{pH} 8.0,300 \mathrm{mM} \mathrm{NaCl}$, and $10 \mathrm{mM}$ imidazole and then loaded on a nickel-chelate affinity resin (Qiagen). DNase $\mathrm{X}$ was eluted with near homogeneity with $150 \mathrm{mM}$ imidazole and dialyzed in TBE buffer.

Cell Culture. L929 fibrosarcoma cells stably transfected with CD95 were maintained in RPMI-1640 supplemented with $10 \%$ heat-inactivated fetal calf serum, 100 units of penicillin/mL, and $0.1 \mathrm{mg}$ of streptomycin/ml (all from Gibco BRL, Eggenstein, Germany). Cells were grown at $37^{\circ} \mathrm{C}$ in a $5 \% \mathrm{CO}_{2}$ atmosphere and passaged by trypsinization. For analyzing the expression of DNase $\mathrm{X}$, the following human cell lines were used: A204 (rhabdomyosarcoma), A549 (lung carcinoma), BJAB (B-cell leukemia), HeLa (cervix carcinoma), HepG2 (hepatoma), HL60 (promyelocyte), HS729.T (rhabdomyosarcoma), HUT78 (T-cell leukemia), K50 (Blymphoblast), KYM (rhabdomyosarcoma), MCF7 (breast adenocarcinoma), MonoMac6 (monocyte), RD (rhabdomyosarcoma), SKW6.4 (B-lymphoblast), and 293 (embryonic kidney).

Transfections. To investigate the effects of DNase X, expression constructs were transiently transfected in L929 cells using the calcium phosphate coprecipitation and electroporation method, respectively. The vector pcDNA-DNase $\mathrm{X}$, which directs the synthesis of DNase $\mathrm{X}$ from the cytomegalovirus enhancer, was obtained by subcloning a PCR-generated cDNA fragment containing the full-coding region of DNase $\mathrm{X}$ into the mammalian expression vector pcDNA3.1 (Invitrogen, The Netherlands). A eukaryotic expression construct encoding DNase X fused N-terminally to GFP was created in the parental plasmid pEGFP (Clontech). In some experiments, also a C-terminally fused GFPDNAse $\mathrm{X}$ construct was used as a control. For calcium phosphate precipitation, $2 \times 10^{6}$ cells were seeded on $10 \mathrm{~mm}$ plates and transfected after overnight incubation. For electroporation, cells were washed in Tris-buffered saline (TBS), resuspended at $2 \times 10^{7}$ cells $/ 0.4 \mathrm{~mL}$ of TBS, and transfected with $15 \mu \mathrm{g}$ of expression plasmids $(75 \mu \mathrm{F}, 500 \mathrm{~V})$. Cells were generally used for the experiments 18 to $24 \mathrm{~h}$ after transfection.

Northern Blot Analysis. Expression of DNase X-specific transcripts was analyzed using a human adult multiple Northern blot from Clontech. Hybridization was carried with ${ }^{32}$ P-labeled full-length cDNA fragments of DNase X and $\beta$-actin according to the recommendations of the manufacturer. The blots were washed to a stringency of $0.5 \mathrm{X} \mathrm{SSC}$ (SSC, $150 \mathrm{mM}$ sodium citrate, $150 \mathrm{mM} \mathrm{NaCl}$ ) and $0.1 \%$ SDS at $62{ }^{\circ} \mathrm{C}$ and then exposed to autoradiography.

Immunoblotting. Immunoblotting was performed following separation of protein samples or cell lysates by $12.5 \%$ or 8 to $15 \%$ gradient SDS-polyacrylamide gel electrophoresis under reducing conditions. If not otherwise indicated, cell lysates were prepared by resuspending $1 \times 10^{6} \mathrm{PBS}$-washed cells in $1 \%$ Triton $\mathrm{X}-100,50 \mathrm{mM}$ Tris- $\mathrm{HCl}, \mathrm{pH} 7.6$, and $150 \mathrm{mM} \mathrm{NaCl}$ containing aprotinin, leupeptin, pepstatin A (each $2 \mu \mathrm{g} / \mathrm{mL}$ ), and $2 \mathrm{mM}$ phenylmethanesulfonyl fluoride 
(PMSF). After electrophoresis, proteins were electroblotted to a poly(vinylidene difluoride) membrane (Amersham, Braunschweig, Germany). The loading and transfer of equal amounts of protein were confirmed by staining the membrane with Ponceau S. Membranes were blocked for $1 \mathrm{~h}$ with 5\% nonfat dry milk powder in TBS and then immunoblotted for $1 \mathrm{~h}$ with the primary antibodies. Membranes were washed four times with TBS $/ 0.05 \%$ Tween-20 and incubated with the peroxidase-conjugated affinity-purified secondary for 1 h. Following extensive washing, the reaction was developed by enhanced chemiluminescent staining.

Induction and Measurement of Cell Death. For induction of cell death, cells were incubated with the indicated proapoptotic agents. Cell death was assessed by the uptake of propidium iodide $(2 \mu \mathrm{g} / \mathrm{mL}$ in PBS) into nonfixed cells and subsequent flow cytometry. Flow cytometric analyses were performed on a FACScalibur (Becton Dickinson, Heidelberg, FRG) using the FSC/FL2 profile and CellQuest analysis software. For detection of nuclear morphological changes, cells were stained with propidium iodide. Samples were observed with an Olympus confocal microscope. In some cases digital images were compiled using Adobe Photoshop 4.0.

Nuclear DNA Fragmentation Assay. The DNA laddercatalyzing activity of DNase $\mathrm{X}$ was determined by DNA fragmentation using HeLa cell nuclei. Nuclei were isolated by lysing cells with $0.5 \% \mathrm{NP}-40$ in $0.25 \mathrm{mM}$ sucrose, 15 $\mathrm{mM}$ Tris- $\mathrm{HCl}, \mathrm{pH} 7.5,60 \mathrm{mM} \mathrm{NaCl}, 15 \mathrm{mM} \mathrm{KCl}, 0.5 \mathrm{mM}$ spermidine, 2 mM EDTA, 0.5 mM EGTA, $15 \mathrm{mM}$ mercaptoethanol, and $0.5 \mathrm{mM}$ PMSF. In the assay, nuclei $\left(2 \times 10^{5}\right)$ were incubated for the indicated times at $37{ }^{\circ} \mathrm{C}$ with the samples in $100 \mu \mathrm{L}$ of TBE buffer containing $20 \%$ glycerol, $5 \mathrm{mM}$ DTT, $1 \mathrm{mg} / \mathrm{mL}$ BSA, $5 \mathrm{mM} \mathrm{CaCl}_{2}$, $5 \mathrm{mM} \mathrm{MgCl}_{2}$, or other ions as indicated. DNA was extracted from the nuclei in $0.25 \mathrm{~mL}$ of TBE containing $0.25 \% \mathrm{NP}-40$ and $0.1 \mathrm{mg} /$ $\mathrm{mL}$ RNase A. After incubation at $37^{\circ} \mathrm{C}$ for $30 \mathrm{~min}$, extracts were treated with $1 \mathrm{mg} / \mathrm{mL}$ proteinase $\mathrm{K}$ for additional 30 $\min$ at $37{ }^{\circ} \mathrm{C}$. Then the extracts were loaded on a $1.5 \%$ agarose gel and run in the presence of $0.5 \mu \mathrm{g} / \mathrm{mL}$ ethidium bromide.

Nuclease Detection Assay. For the identification of DNase activity, an activity gel system (zymogram) was used. DNase $\mathrm{X}$-containing protein samples were electrophoresed under reducing conditions in $12.5 \% \mathrm{SDS}$-polyacrylamide gels saturated with $10 \mu \mathrm{g} / \mathrm{mL}$ salmon sperm DNA and $2 \mathrm{mM}$ EDTA. After electrophoresis, the gels were extensively washed with $40 \mathrm{mM}$ Tris- $\mathrm{HCl}$, pH 7.6, to remove SDS, then incubated with $40 \mathrm{mM}$ Tris- $\mathrm{HCl}, \mathrm{pH}$ 7.6, $2 \mathrm{mM} \mathrm{MgCl}_{2}$, and $2 \mathrm{mM} \mathrm{CaCl} 2$ overnight and finally stained with $1 \mu \mathrm{g} / \mathrm{mL}$ ethidium bromide. Apparent nuclease activities were detected as dark areas on a fluorescent background after transillumination of the gels with UV light. To avoid the problem of detecting false positive signals generated by DNA-binding proteins, in addition, radioactive activity gel analysis was performed. In this assay, DNA was labeled with $\gamma-\left[{ }^{32} \mathrm{P}\right] \mathrm{ATP}$, and $2 \times 10^{5} \mathrm{cpm} / \mathrm{mL}$ of the labeled DNA was incorporated into the gel. To determine nuclease activity, additionally a radioactive DNA precipitation assay was employed. Protein fractions containing DNase $\mathrm{X}$ were incubated with $1 \mu \mathrm{g}$ of ${ }^{32} \mathrm{P}$-end-labeled DNA in $200 \mu \mathrm{L} 40 \mathrm{mM}$ Tris-HCl, pH 7.6, $2 \mathrm{mM} \mathrm{MgCl} 2$, and $2 \mathrm{mM} \mathrm{CaCl}_{2}$ at $37{ }^{\circ} \mathrm{C}$. After $30 \mathrm{~min}$, the reaction was stopped by precipitation for $1 \mathrm{~h}$ at $0{ }^{\circ} \mathrm{C}$ with
$200 \mu \mathrm{L}$ of $10 \%$ trichloroacetic acid. The nondigested DNA was collected on $\mathrm{GF} / \mathrm{C}$ filters and following extensive washing of the filters quantified in a scintillation counter.

Fluorogenic Substrate Assay for Caspases. Cytosolic cell extracts were prepared by lysing cells in a buffer containing 1\% NP-40, $200 \mathrm{mM} \mathrm{NaCl}, 20 \mathrm{mM}$ Tris- $\mathrm{HCl}, \mathrm{pH}$ 7.4, $2 \mu \mathrm{g} /$ $\mathrm{mL}$ aprotinin, $2 \mu \mathrm{g} / \mathrm{mL}$ leupeptin, and $1 \mathrm{mM}$ PMSF. Caspase activities were determined by incubation of cell lysates with $50 \mu \mathrm{M}$ of the fluorogenic substrate DEVD-AMC ( $N$-acetylAsp-Glu-Val-Asp-aminomethylcoumarin, Bachem, Heidelberg, Germany) in $200 \mu \mathrm{L}$ buffer containing $10 \mathrm{mM}$ Hepes, $\mathrm{pH}$ 7.4, $220 \mathrm{mM}$ mannitol, $68 \mathrm{mM}$ sucrose, $2 \mathrm{mM} \mathrm{NaCl}$, $2.5 \mathrm{mM} \mathrm{KH}_{2} \mathrm{PO}_{4}, 0.5 \mathrm{mM}$ EGTA, $2 \mathrm{mM} \mathrm{MgCl}_{2}, 5 \mathrm{mM}$ pyruvate, $1 \mathrm{mM}$ PMSF, and $1 \mathrm{mM}$ DTT. The release of aminomethylcoumarin was measured by fluorometry using an excitation wavelength of $360 \mathrm{~nm}$ and emission wavelength or $475 \mathrm{~nm}$.

In Vitro Caspase Cleavage. For in vitro cleavage experiments, DNase X was incubated for $2 \mathrm{~h}$ at $37^{\circ} \mathrm{C}$ with different concentrations of recombinant caspases in $65 \mu \mathrm{L}$ cell lysis buffer additionally containing $5 \mathrm{mM}$ DTT. Caspase-1, -6, and -7 were expressed in $E$. coli as glutathione-S-transferase fusion proteins in the vector pGEX5. Caspase-3 was expressed as a histidine fusion protein using the bacterial expression vector $\mathrm{pQE}-9$ and purified by nickel-chelate affinity chromatography. Following incubation with the caspases, protein cleavage was investigated by SDS-PAGE.

Deglycosylation Experiments. To investigate the glycosylation state of DNase $\mathrm{X}$, experiments with $\mathrm{N}$-glycosidase F were performed. Briefly, L929 cells were transfected with pcDNA-DNase X. After $24 \mathrm{~h}$ cell extracts were prepared and denatured by a $10 \mathrm{~min}$ incubation at $95^{\circ} \mathrm{C}$ in $0.5 \%$ SDS and $1 \% \beta$-mercaptoethanol. Deglycosylation with $N$-glycosidase $\mathrm{F}$ was performed for $1 \mathrm{~h}$ at $37{ }^{\circ} \mathrm{C}$ according to the instructions of the manufacturer (New England Biolabs, Beverly, MA). The extracts were then analyzed by SDSPAGE and immunoblotting.

\section{RESULTS}

Biochemical Characterization of Recombinant DNase X. The cDNA of DNase X has been isolated previously by two of us in an attempt to identify genes present in selected cosmid contigs from the Xq28 region (30). The DNase X gene is located on the $\mathrm{X}$ chromosome and encodes a 302 amino acid protein with $39 \%$ identity to DNase I. To characterize the biochemical properties of the protein, we first expressed DNase $\mathrm{X}$ as a histidine-tagged fusion protein in E. coli. By metal chelate chromatography, DNase X could be purified to near homogeneity. The protein purification was approximately 60 -fold, with a yield of $12 \%$. As revealed by SDS-PAGE followed by staining with Coomassie brilliant blue or immunoblotting with an anti-histidine tag antibody, DNase $\mathrm{X}$ migrated as a protein band of approximately $36 \mathrm{kDa}$ (Figure 1A). To probe the presence of nuclease activity of the recombinant protein, we performed zymograms on SDS gels saturated with salmon sperm DNA. Following renaturation, nuclease activity was detected at 36 $\mathrm{kDa}$ (Figure 1A). In addition, a small amount of DNase activity was present at approximately $70 \mathrm{kDa}$, representing presumably a dimer of DNase X.

In an attempt to characterize DNase $X$ further, we employed a transfer test with isolated nuclei which are a 

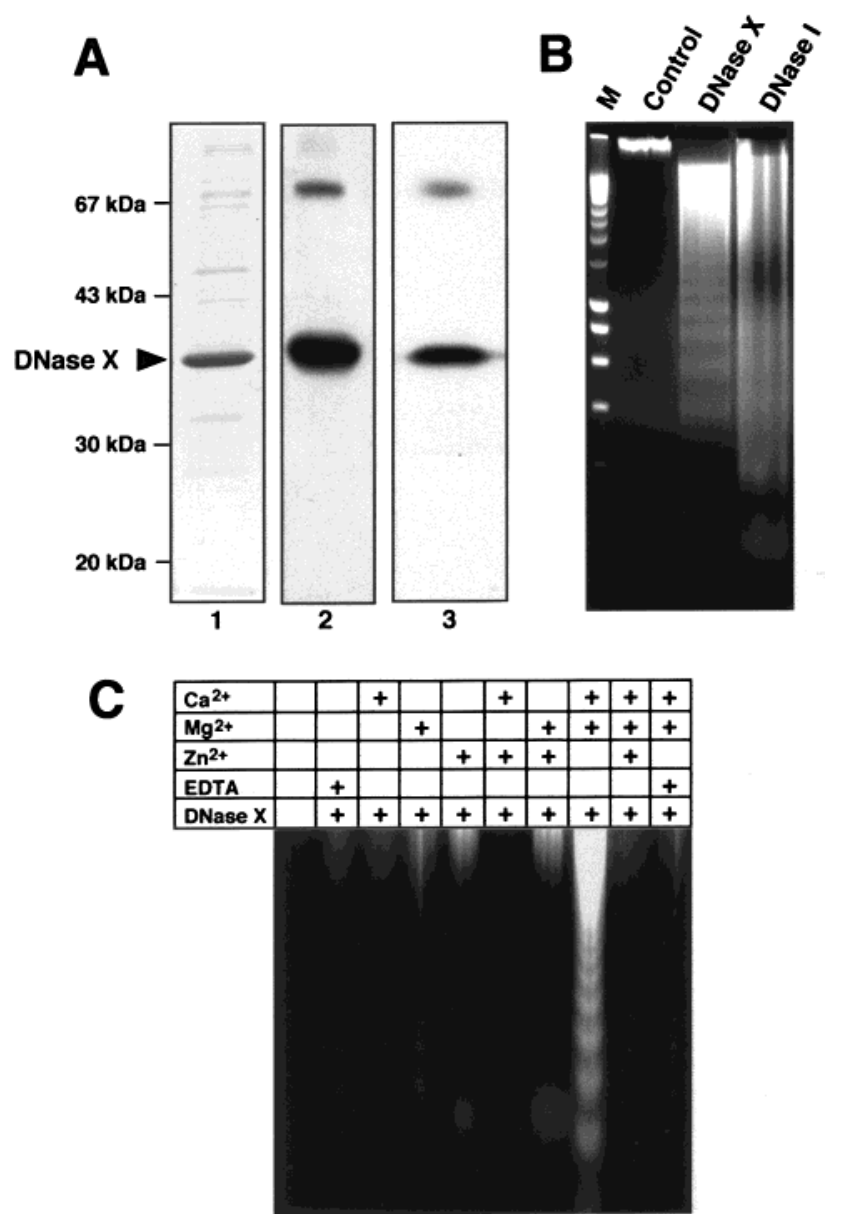

FIGURE 1: Expression and biochemical features of recombinant DNase X. (A) Full-length DNase X was expressed as a histidinetagged fusion protein and purified by metal chelate chromatography under nondenaturating conditions. Following electrophoresis in $12.5 \%$ SDS - polyacrylamide gels under reducing conditions DNase $\mathrm{X}$ (3 $\mu \mathrm{g}$ of protein) was detected by Coomassie brilliant blue staining (lane 1), immunoblot analysis with an anti-histidine tag antibody (lane 2), or in a zymogram using DNA-containing gels and ethidium bromide staining (lane 3 ). The position of DNase $X$ is indicated by an arrowhead. Note the protein band of approximately $70 \mathrm{kDa}$ which presumably represents a dimer of DNase X. (B) Recombinant DNase X has internucleosomal DNA fragmentation activity. One microgram DNase $\mathrm{X}$ was added to isolated HeLa cell nuclei in the presence of $\mathrm{Ca}^{2+}$ and $\mathrm{Mg}^{2+}$. After incubation at $37^{\circ} \mathrm{C}$ for $90 \mathrm{~min}$, DNA was extracted from the reaction mixture, loaded on a $1.5 \%$ agarose gel and stained with ethidium bromide. Bovine pancreatic DNase I $(1 \mu \mathrm{g})$ was used as a positive control. $\mathrm{M}$ : molecular size marker. (C) DNase $\mathrm{X}$ requires the presence of $\mathrm{Ca}^{2+}$ and $\mathrm{Mg}^{2+}$ ions. DNase $\mathrm{X}$ was incubated with isolated nuclei for $90 \mathrm{~min}$ in TBE buffer containing either $5 \mathrm{mM} \mathrm{CaCl}_{2}, 5 \mathrm{mM}$ $\mathrm{MgCl}_{2}, 5 \mathrm{mM} \mathrm{ZnCl}_{2}, 20 \mathrm{mM}$ EDTA, or combinations thereof. After 90 min low molecular mass DNA was isolated and separated on an agarose gel. DNase activity was detected as an apoptosis-like DNA ladder.

more physiological substrate than naked DNA. The addition of DNase $\mathrm{X}$ to isolated HeLa cell nuclei resulted in the appearance of a typical apoptotic DNA ladder (Figure 1B). Interestingly, DNase I gave rise to a more fuzzy pattern of DNA digestion. The DNA ladder-catalyzing activity of DNase $\mathrm{X}$ required the presence of $\mathrm{Ca}^{2+}$ and $\mathrm{Mg}^{2+}$ ions, whereas it was completely inhibited by the presence of $\mathrm{Zn}^{2+}$ or the bivalent ion chelator EDTA in the reactivation buffer (Figure 1C). Moreover, enzyme activity was detectable only at neutral $\mathrm{pH}$ (data not shown). Thus, the $\mathrm{pH}$ and ion dependencies of DNase $\mathrm{X}$ are similar to DNase I.

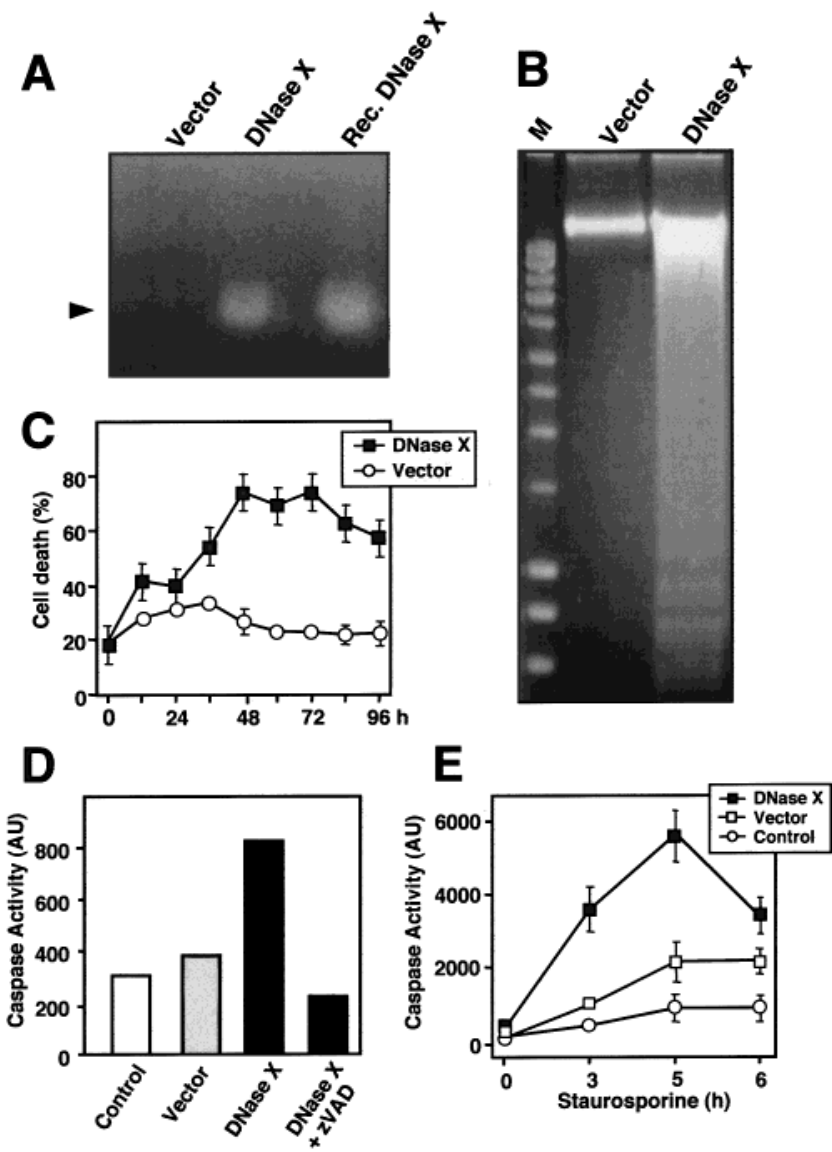

FIGURE 2: Transient expression of DNase $X$ triggers activation of nuclease activity, DNA fragmentation, caspases, and cell death. (A) Induction of nuclease activity. L929 cells were transfected with a plasmid encoding DNase X or the vector control pcDNA3. Transient transfection by electroporation resulted in a transfection efficiency of about $80 \%$. At $24 \mathrm{~h}$ posttransfection, cell lysates were prepared and loaded on a SDS gel containing ${ }^{32} \mathrm{P}$-end-labeled DNA. Nuclease activity was detected by autoradiography. Recombinant DNase X was used as a positive control. (B) Induction of DNA fragmentation. Twenty-four hours after transfection, genomic DNA was isolated from the cells and subjected to agarose gel electrophoresis. (C) Induction of cell death. Following transfection with the DNase $\mathrm{X}$-encoding plasmid (filled squares) or the vector control (open circles), L929 cells were incubated for $16 \mathrm{~h}$ and washed twice with medium to remove cellular debris. After further incubation for the indicated times, cell death was determined by the uptake of propidium iodide into dead cells and flow cytometry. (D) Induction of caspase activity. Cells were left untreated or transfected with either the DNase X encoding construct or the vector control. After $20 \mathrm{~h}$ of incubation in the absence or presence of the caspase inhibitor zVAD $(50 \mu \mathrm{M})$, cell lysates were prepared, incubated with the flourogenic caspase substrate DEVD-AMC and measured in a fluorometer. (E) Enhancement of staurosporine-induced caspase activation by DNase X. L929 cells were left untreated (open circles) or transfected with either the DNase X construct (filled squares) or the vector control (open squares). After $16 \mathrm{~h}$ cells were treated for the indicated times with staurosporine $(2 \mu \mathrm{M})$ and then analyzed for caspase activation with the substrate DEVD-AMC.

Transient Overexpression of DNase X Induces Oligosomal DNA Fragmentation and Apoptosis. In the next series of experiments, we investigated the effects of DNase X in intact cells by transient transfection experiments. After expression of a CMV enhancer-controlled DNase X construct in L929 cells, nuclease activity was measured in cell lysates prepared $24 \mathrm{~h}$ posttransfection. As shown by zymogram analysis, enzyme activity was strongly increased upon overexpression of DNase X (Figure 2A). In contrast, no nuclease activity 

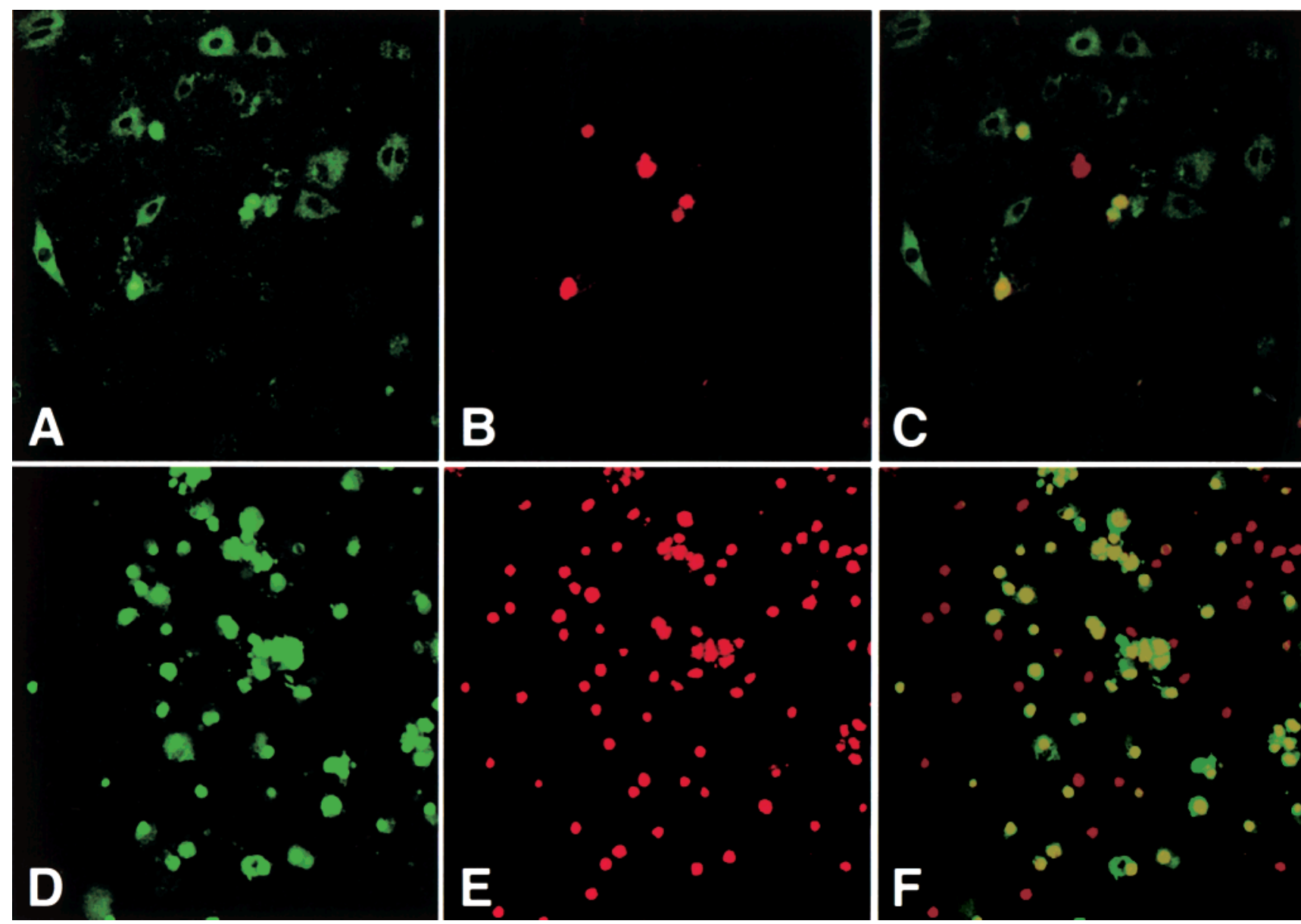

FIGURE 3: Intracellular localization of DNase X. L929 cells were transfected with a GFP-DNase X fusion plasmid and then either left untreated for $24 \mathrm{~h}(\mathrm{~A}-\mathrm{C})$ or incubated for $6 \mathrm{~h}$ with $2 \mu \mathrm{M}$ staurosporine $18 \mathrm{~h}$ after transfection (D-F). After staining with propidium iodide (red staining) nonfixed cells were inspected for the localization of DNase X (A, D) or nuclear morphology (B, E) by fluorescence microscopy. Composite images, in which the green staining of DNase $\mathrm{X}$ was superimposed to the red staining $(\mathrm{C}, \mathrm{F})$, revealed a nuclear localization of the DNase during staurosporine treatment, as indicated by the merged yellow color in most apoptotic cells.

was detected in cells transfected with the parental vector pcDNA3. Cells transfected with DNase X displayed also genomic DNA degradation which did not occur in control cells (Figure 2B). Furthermore, overexpression of DNase X resulted in a strong time-dependent induction of cell death, whereas only a minor cytotoxic effect was observed in the vector-control transfected cells (Figure 2C).

Because caspases are the central regulators of apoptotic cell death, we investigated the effect of DNase X expression on caspase proteolytic activity. Cells were transfected with the DNase X encoding construct, and $20 \mathrm{~h}$ later, caspase activity was measured in the cell lysates with the fluorogenic substrate DEVD-AMC. As shown in Figure 2D, overexpression of DNase $\mathrm{X}$ resulted in an increase of caspase activity that was almost completely prevented by the broad caspase inhibitor zVAD. Furthermore, DNase X expression strongly enhanced caspase activation induced by the apoptotic agent staurosporine (Figure 2E). Although cell death induced by staurosporine was similarly potentiated by DNase $\mathrm{X}$ overexpression, zVAD was unable to efficiently protect from cell death (data not shown). This indicated that activation of caspases by DNase $\mathrm{X}$ is downstream of nuclear damage and DNA fragmentation.

Cellular Localization of DNase X. To gain further insights into the mechanism of DNase $X$ action, we performed transfections with a green fluorescent protein (GFP) reporter construct of DNase $X$ and subsequent fluorescence microscopy. In healthy L929 cells, DNase X was found mainly in the cytoplasm and excluded from the nucleus (Figure 3A). Interestingly, when apoptosis was induced by staurosporine, it was found that DNase $\mathrm{X}$ became more concentrated in the nuclear compartment (Figure 3D). A merged two-color fluorescence image of staurosporine-treated cells stained green with GFP-DNase X and red with the DNA dye propidium iodide clearly revealed double labeling of the apoptotic nuclei (Figure 3F). In contrast, nuclear accumulation was not observed when cells were transfected with the GFP-control vector (data not shown). These results indicate that DNase $\mathrm{X}$ is obviously expressed in the cytoplasm, but gains access to nuclear DNA during apoptosis.

Effect of Caspases on DNase X. Since DNase X was redistributed during apoptosis, we speculated that its activation may be mediated by posttranslational modifications. Interestingly, DNase $\mathrm{X}$ harbors two potential aspartate cleavage sites $\left(\mathrm{FNAD}_{186}\right.$ and $\left.\mathrm{DGED}_{215}\right)$ for caspases. To investigate the possibility that DNase $\mathrm{X}$ was cleaved by caspases, we incubated recombinant DNase $\mathrm{X}$ in vitro with caspase-3. As detected by SDS-PAGE (Figure 4A) even high concentrations of caspase-3, visible in the gel as the 17 and $12 \mathrm{kDa}$ subunits, were unable to cleave DNase X. A similar lack of cleavage was observed following treatment of DNase $X$ with caspase-1, -6 , and -7 (Figure 4B). In 

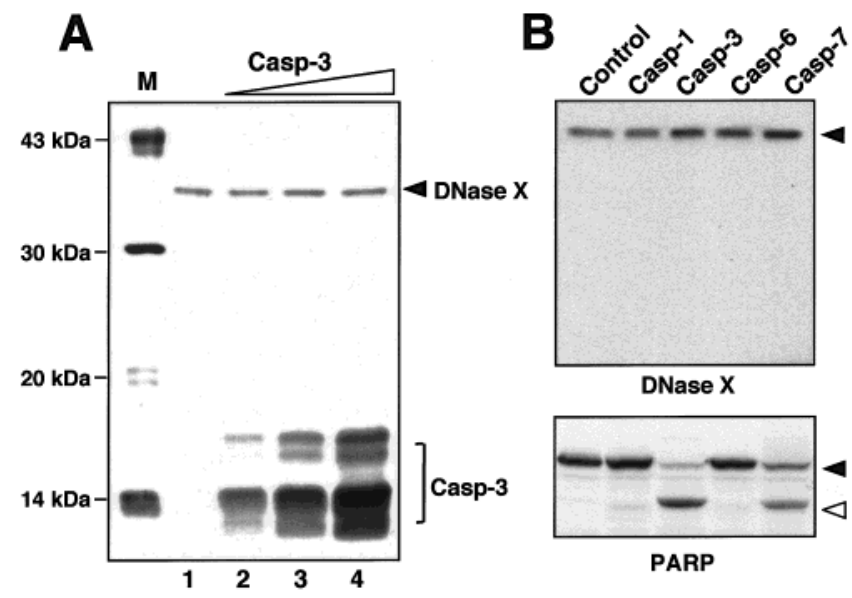

DNase $\mathbf{X}$
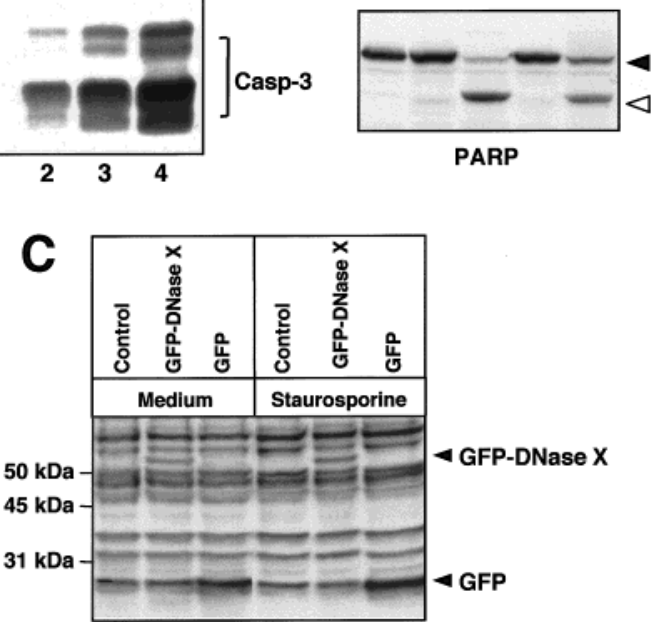

FIGURE 4: DNase $\mathrm{X}$ is not cleaved either by caspases or during cell death. (A) Effect of caspase-3. Increasing amounts of caspase-3 $(0,2,4$, and $8 \mu \mathrm{g})$ were incubated in a $30 \mu \mathrm{L}$ volume with $1 \mu \mathrm{g}$ of recombinant DNase X. After $2 \mathrm{~h}$ of incubation at $37^{\circ} \mathrm{C}$, the reaction mixture was loaded on a SDS gel and stained by Coomassie brilliant blue. The location of DNase $\mathrm{X}$ and the caspase- 3 subunits is indicated. $M$ shows the position of molecular mass markers. (B) Effect of different caspases on DNase X processing. Recombinant caspase-1, $-3,-6$, or -7 were incubated as described above with DNase X (upper panel) or recombinant PARP (lower panel). After $2 \mathrm{~h}$ the reaction mixtures were analyzed by SDS-PAGE. It should be noted that PARP is not a substrate of caspase-1 and -6. (C) DNase $\mathrm{X}$ is not proteolytically processed during apoptosis induced by staurosporine. L929 cells were either left untreated or transfected with the GFP-DNase X fusion construct or the GFP vector control. Eighteen hours after transfection cell death was induced by incubation with staurosporine $(2 \mu \mathrm{M})$. Cells were harvested after 6 $\mathrm{h}$ and subjected to immunoblot analysis with anti-GFP antibody. The positions of GFP-tagged DNase X and GFP are indicated.

contrast, caspase-3 and -7 efficiently cleaved their substrate poly(ADP-ribose)polymerase (PARP) into the characteristic $85 \mathrm{kDa}$ fragment, confirming that the caspases were enzymatically active.

Because during apoptosis several caspases may be activated, we further investigated a potential proteolytic processing of DNase $\mathrm{X}$ in living cells induced to undergo cell death by different agents. In L929 cells transfected with the GFPDNase X construct, the DNase X fusion protein was detected as a protein of approximately $58 \mathrm{kDa}$. Neither the treatment of cells with staurosporine (Figure 4C) nor the treatment with agonistic anti-CD95 antibodies or TNF, which induces necrosis in these cells (31), induced the processing of DNase X, although cell death induced by these agents was clearly visible by microscopic inspection (data not shown). Taken together, we consider it rather unlikely that DNase X was modified by proteolytic processing during cell death. The experiments in intact cells further suggest that the failure of caspases to cleave DNase $\mathrm{X}$ in vitro was not due to the denaturation or other modifications of recombinant DNase X.
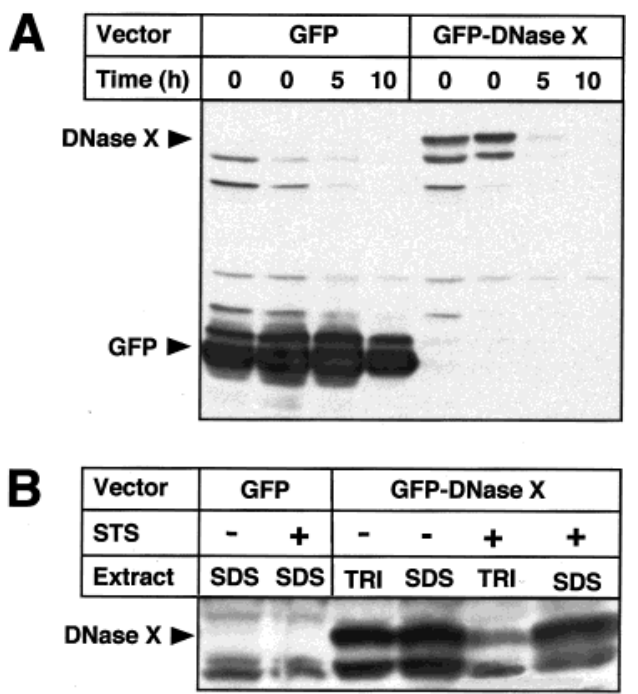

FIGURE 5: DNase $\mathrm{X}$ becomes detergent-resistant during apoptosis. (A) Cells were transfected with the GFP vector or the GFP-DNase $\mathrm{X}$ fusion construct. Twenty-four hours later cells were treated for the indicated times with $2 \mu \mathrm{M}$ staurosporine. Cell lysates were prepared by extraction with $1 \%$ Triton X-100, subjected to SDSPAGE, and then immunoblotted with anti-GFP. (B) Effects of different lysis conditions. Following treatment of the transfected cells with staurosporine (STS) for $5 \mathrm{~h}$ as described above, cells were lysed either with $1 \%$ Triton X-100, or $2 \%$ SDS. The lysates were investigated for the presence of GFP-DNase X by SDSPAGE and immunoblot analysis with anti-GFP. The position of GFP-DNase $\mathrm{X}$ is indicated by an arrowhead.

DNase X Becomes Detergent-Resistant during Apoptosis. While investigating posttranslational modifications of DNase $\mathrm{X}$, we noticed that the solubility of DNase $\mathrm{X}$ with nonionic detergents became altered during apoptosis. In Figure 5A, cells were transfected with the GFP-DNase X construct and induced to undergo apoptosis by staurosporine. When cells were subsequently lysed with Triton X-100 and subjected to SDS-PAGE, a time-dependent loss of the DNase Xspecific protein band was observed. In contrast, the amount of GFP in cells transfected with the parental plasmid remained rather unchanged. Interestingly, no loss of DNase $\mathrm{X}$ in response to staurosporine (Figure 5B) or anti-CD95 (data not shown) was detected when the cells were lysed with SDS. This indicated that DNase $\mathrm{X}$ was not degraded or lost into supernatants during apoptosis, but became rearranged to a detergent-resistant structure during apoptosis. Since detergent-insoluble fractions contain several structural and cytoskeletal proteins which are often involved in protein translocations, we investigated whether DNase $\mathrm{X}$ was associated with microtubuli or other filamentous proteins. We did not find that incubation of cells at low temperature, which induces tubulin disassembly, changed the solubility of DNase X (data not shown). In addition, neither destruction of the actin filament system by cytochalasin nor the breakdown of the microtubuli system by vinblastin altered its solubility (data not shown). Thus, these findings show that DNase $\mathrm{X}$ becomes detergent-resistant during apoptosis, but presumably does not associate with microtubuli or actin filaments.

Expression of DNase X in Human Tissues and Cell Lines. Because DNase I-like nucleases are expressed in a rather tissue-specific manner, we analyzed the expression pattern of DNase X. By Northern blot analysis, a strong hybridization 
to the DNase $\mathrm{X}$ probe was found in cardiac and skeletal muscle (Figure 6A). Other tissues except brain only revealed a faint expression signal. DNase X mRNA was detected as two major transcripts of 2.2 and $2.5 \mathrm{~kb}$, with differences in the relative abundance. Whereas in heart muscle the $2.5 \mathrm{~kb}$ transcript was predominant, skeletal muscle expressed mainly the smaller transcript. Furthermore, transcripts of approximately $3.5 \mathrm{~kb}$ were weakly expressed in other tissues.

To examine DNase $\mathrm{X}$ protein expression, we generated a specific antiserum by immunization of rabbits with the purified recombinant protein. By Western blot analysis of a number of different cell lines, immunoreactivity was detected with two protein bands of approximately 35 and $37 \mathrm{kDa}$ (Figure 6B). Expression of DNase X was found in A549 lung carcinoma, KYM rhabdomyosarcoma, MCF7 breast carcinoma, and HepG2 hepatoma cells, whereas most other cell lines, in particular hematopoietic cells, revealed no or only weak expression of DNase X. Since the immunoblot analyses revealed that DNase $\mathrm{X}$ is expressed in different size variants, we investigated its glycosylation state. Following transfection of L929 cells, DNase X migrated as a protein doublet of approximately 35 and $37 \mathrm{kDa}$ (Figure 6C, left panel). Treatment of cell lysates with $\mathrm{N}$-glycosidase resulted in the complete disappearance of the upper protein band, thus indicating its glycosylation. Additionally, it was examined whether DNase X was secreted into the culture medium. However, we could not detect a DNase X-specific protein band by immunoprecipitation of supernatants from either untreated or staurosporine-stimulated cells after transfection with the DNase $\mathrm{X}$ construct (Figure 6C, right panel). Thus, these data indicate that DNase X can be glycosylated but is not secreted into the culture supernatant.

\section{DISCUSSION}

In the present study we describe the characterization of DNase $\mathrm{X}$ and its involvement in DNA degradation. The sequence of DNase $\mathrm{X}$ has been originally identified by EST database researches and by expression screening of cosmid contigs of the Xq28 region $(30,32,33)$. It encodes a 302 amino acid protein with $39 \%$ identity to DNase I. Most of the exon-intron boundaries of DNase X and DNase I are similar, indicating that both genes evolved from a common ancestor (30). To investigate the biochemical properties and the relationship to DNase I, we analyzed the cation requirement and the $\mathrm{Zn}^{2+}$ sensitivity of DNase X. Similarly to DNase I, the catalytic activity of DNase $X$ required the presence of $\mathrm{Ca}^{2+}$ and $\mathrm{Mg}^{2+}$ ions and was inhibited by $\mathrm{Zn}^{2+}$ and metal chelators. These DNase I-like biochemical features are supported by the sequence similarity and the conserved $\mathrm{Ca}^{2+}$ - and DNA-binding residues present in both molecules. Unlike DNase I, however, DNase X possesses no conserved actin-binding domain which would predict that it is not inhibited by monomeric actin.

DNase I was the first $\mathrm{Ca}^{2+}$-dependent endonuclease characterized in detail (34). Very recently, several other related proteins forming a family of DNase I-like endonucleases have been described. Besides DNase X, these include human DNAS1L2 and DNAS1L3 $(35,36)$. It is remarkable that all enzymes appear to be expressed in a highly tissuespecific manner. DNase I is constitutively expressed in kidney, parotid gland, and predominantly in pancreas,
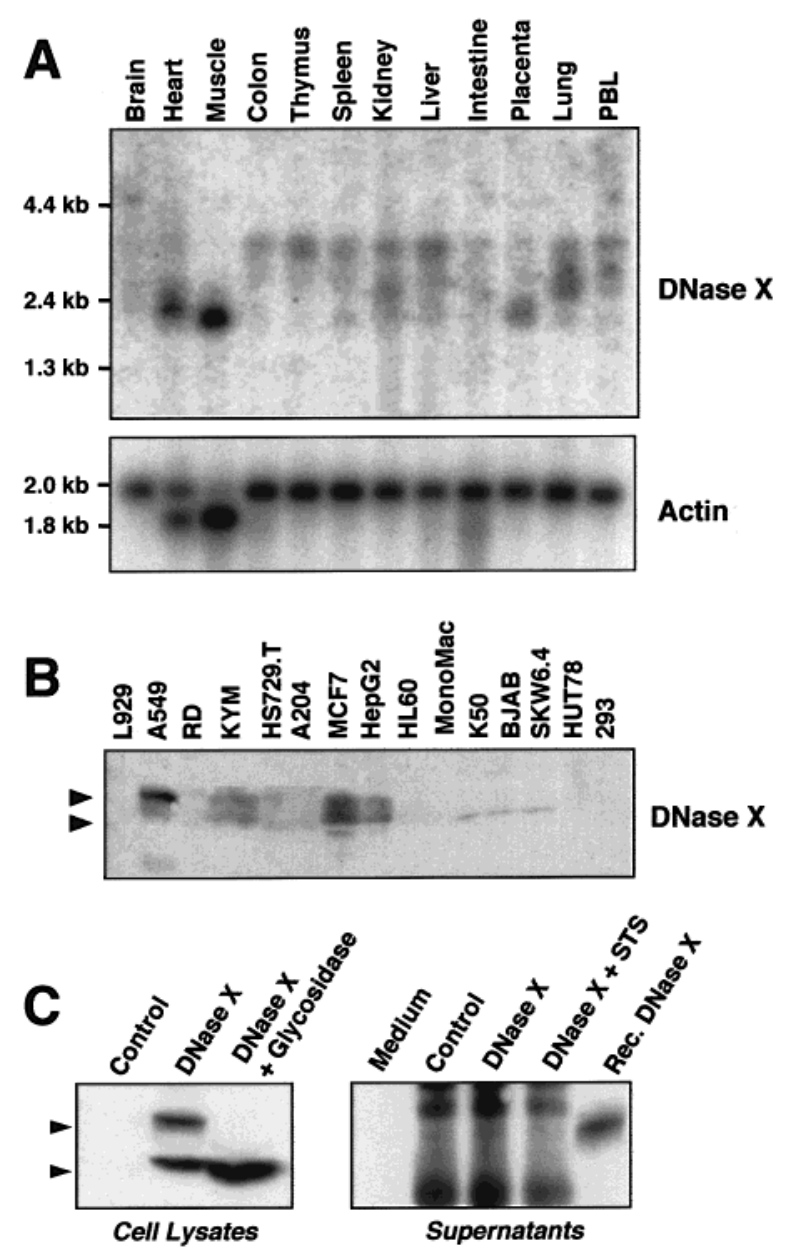

FIGURE 6: Expression of DNase X mRNA and protein in different human tissues and cell lines. (A) Northern blot analysis. ${ }^{32} \mathrm{P}-$-labeled cDNA probes for DNase $\mathrm{X}$ and $\beta$-actin were used to sequentially probe a multiple tissue Northern blot of poly $(\mathrm{A})^{+}$RNA from different tissues. The positions of molecular size markers are shown on the left. PBL: peripheral blood leukocytes. (B) Western blot analysis. Lysates of cell lines $\left(1 \times 10^{6}\right.$ cells $)$ from different cellular origin were subjected to SDS-PAGE and analyzed by immunoblotting with a DNase X-specific antiserum. The antiserum was generated by immunization of rabbits with recombinant DNase $\mathrm{X}$ and purified by protein $\mathrm{G}$ sepharose. The arrowheads indicate the position of two immunospecific protein bands of approximately 35 and $37 \mathrm{kDa}$. No immunoreactivity was obtained with the preimmune serum. (C) DNase X is glycosylated, but not efficiently secreted. (Left panel) Glycosylation of DNase X. Cells were either left untreated or transfected with the pcDNA-DNase X plasmid. After $24 \mathrm{~h}$, cell lysates were prepared and either left untreated or incubated with $\mathrm{N}$-glycosidase for $1 \mathrm{~h}$. The reaction mixtures were analyzed by immunoblot analysis with anti-DNase X. (Right panel) Supernatants of L929 cells or DNase X overexpressing cells, which had been incubated for $6 \mathrm{~h}$ in the presence and absence of staurosporine (STS), were harvested $30 \mathrm{~h}$ after transfection and analyzed for the presence of DNase $\mathrm{X}$ by immunoprecipitation and subsequent SDS-PAGE. Recombinant DNase $\mathrm{X}$ was used as a positive control.

consistent with its assumed DNA digestive function (28). There is also evidence that induction of DNase I expression is involved in apoptosis of a number of nonsecretory cells, such as thymocytes, terminally differentiated keratinocytes and prostate epithelial cells following androgen withdrawal (37-39). DNAS1L2 tends to be primarily present in brain, whereas DNAS1L3 has been found mainly in macrophages of liver and spleen $(34,35)$. In our experiments, we observed that expression of DNase $\mathrm{X}$ mRNA was rather restricted to 
muscle tissues. Northern blot analysis revealed that DNase $\mathrm{X}$ was expressed as different splice variants. Whereas in heart tissue a mRNA of $2.5 \mathrm{~kb}$ was found, smaller transcripts of $2.2 \mathrm{~kb}$ were present in skeletal muscle. At the protein level, DNase $\mathrm{X}$ was detected in tumor cells of different origin. Interestingly, we found that DNase $\mathrm{X}$ could occur as an $\mathrm{N}$-glycosylated form. In contrast to DNase I that contains several potential glycosylation sites, only one glycosylation site is present in DNase $\mathrm{X}$ at residue 261. However, at variance with DNase I, we did not find that DNase $\mathrm{X}$ was secreted, suggesting that it acted mainly intracellularly.

Our experiments revealed that recombinant DNase X was capable of inducing not only DNA degradation, but also the formation of internucleosomal DNA fragments when incubated with isolated nuclei. Importantly, also overexpression of DNase X triggered chromatin fragmentation, which finally led to pyknosis and apoptotic cell death. In addition, the transfected cells were sensitized to different apoptotic agents. This proapototic effect of DNase X was accompanied by increased caspase activation, which was presumably mediated by DNA damage rather than by a direct effect of DNase X on caspase activity. This assumption is supported by our finding that caspase inhibitors failed to prevent cell death in response to DNase $\mathrm{X}$ overexpression (data not shown).

An important question is how DNase $\mathrm{X}$ gains access to nuclear DNA during apoptosis. It has been shown that some nucleases are activated either by posttranslational processing of an inactive precursor or the proteolytic dissociation of an inhibitory subunit. Indeed, sequence analysis revealed two conserved caspase cleavage sites in DNase X. However, DNase $X$ was neither cleaved in vitro by different caspases nor in intact cells during apoptosis. This indicates that the caspase cleavage sites are presumably masked due the steric conformation of DNase X. Furthermore, no proteolytic processing was observed in TNF-stimulated L929 cells which undergo necrosis involving the activation of serine proteases (31). Thus, we consider it unlikely that DNase $\mathrm{X}$ has to be proteolytically processed in order to become activated. This is supported by the finding that full-length recombinant DNase X exerts DNA-laddering as well as nuclease activity at $35 \mathrm{kDa}$. Interestingly, some amount of DNase $\mathrm{X}$ revealed activity at $70 \mathrm{kDa}$ which presumably represented a dimer. This oligomerization may be mediated by the helix-loophelix domain located at the C-terminus of DNase X.

Following transient transfection, DNase $\mathrm{X}$ was mainly localized in the cytoplasm, whereas upon induction of apoptosis a significant amount became concentrated at the perinuclear space and inside the nucleus. It is possible that this translocation may be facilitated by a damage of the nuclear envelope. Interestingly, during apoptosis, DNase X became rearranged in that it changed from an insoluble form to a structure resistant to nonionic detergents. The mechanism underlying this phenomenon is unknown, but it is conceivable that DNase $\mathrm{X}$ associates with structural proteins or tightly binds to chromatin structures. We found no evidence that DNase $\mathrm{X}$ anchors to microtubuli which are implicated in protein translocation. In addition, neither the destruction of the actin filament system nor the breakdown of the microtubule system rendered the protein soluble or affected protein translocation. It is interesting to note that, following treatment of cells with apoptotic stimuli, also significant amounts of hsp25 and hsp70 and well as $\mathrm{p} 21^{\text {wafl }}$ protein have been reported to be translocated to the nucleus, where they become resistant to detergent extraction $(40,41)$. Future studies will have to analyze whether the translocation of DNase X and its rearrangement are directly linked to each other and whether posttranslational modification is required for these processes. In addition, it will be interesting to analyze whether DNase X, due to its abundant expression in muscle tissues, participates in myopathies, myocardial infarction, or other forms of muscle and cardiac failure.

\section{REFERENCES}

1. Arends, M. J., Morris, R. G., and Wyllie, A. H. (1990) Am. J. Pathol. 136, 593-608.

2. Compton, M. M. (1992) Cancer Metastasis Rev. 11, 105119.

3. Peitsch, M. C., Mannherz, H. G., and Tschopp, J. (1994) Trends Cell Biol. 4, 37-41.

4. Rathmell, J. C., and Thompson, C. B. (1999) Annu. Rev. Immunol. 17, 781-828.

5. Los, M., Wesselborg, S., and Schulze-Osthoff, K. (1999) Immunity 10, 629-639.

6. Walker, P. R., and Sikorska, M. (1997) Biochem. Cell Biol. $75,287-299$.

7. Montague, J. W., Gaido, M. L., Frye, C., and Cidlowski, J. A. (1994) J. Biol. Chem. 269, 18877-18880.

8. Polzar, B., and Mannherz, H. G. (1990) Nucleic Acids Res. $18,7151$.

9. Peitsch, M. C., Polzar, B., Stephan, H. Crompton, T., MacDonald, H. R., Mannherz, H. G., and Tschopp, J. (1993) EMBO J. 12, 371-377.

10. Shiokawa, D., and Tanuma, S. (1998) Biochem. J. 332, 713720.

11. Pandey, S., Walker, P. R., and Sikorska, M. (1997) Biochemistry 36, 711-720.

12. Kawabata, H., Anzai, N., Masutani, H., Hirama, T., Hishita, T., Dodo, M., Masuda, T., Yoshida, Y., and Okuma, M. (1997) Biochem. Biophys. Res. Commun. 233, 133-138.

13. Yasuda T., Takeshita, H., Iida, R., Nakajima, T., Hosomi, O., Nakashima, Y., and Kishi, K. (1998) J. Biol. Chem. 273, 2610-2616.

14. Krieser, R. J., and Eastman, A. (1998) J. Biol. Chem. 273, 30909-30914.

15. Torriglia, A., Perani, P., Brossas, J. Y., Chaudun, E., Treton, J., Courtois, Y., and Counis, M. F. (1998) Mol. Cell Biol. 18, 3612-3619.

16. Segal-Bendirdjian, E., and Jacquemin-Sablon, A. (1995) Exp. Cell Res. 218, 201-212.

17. Belmokhtar, C. A., Torriglia, A., Counis, M. F., Courtois, Y., Jacquemin-Sablon, A., and Segal-Bendirdjian, E. (2000) Exp. Cell Res. 254, 99-109.

18. Liu, X., Zou, H., Slaughter, C., and Wang, X. (1997) Cell 89, $175-184$.

19. Enari, M., Sakahiera, H., Yokoyama, H., Okawa, K., Iwamatsu, A., and Nagata, S. (1998) Nature 391, 43-50.

20. Sakahira, H., Enari, M., and Nagata, S. (1998) Nature 391, 96-99.

21. Oberhammer, F., Fritsch, G., Schmied, M., Pavelka, M., Printz, D., Purchio, T., Lassmann, H., and Schulte-Hermann, R. (1993) J. Cell Sci. 104, 317-326.

22. Schulze-Osthoff, K., Walczak, H., Droge, W., and Krammer, P. H. (1994) J. Cell Biol. 127, 15-20.

23. Oberhammer, F., Wilson, J. W., Dive, C., Morris, I. D., Hickman, J. A., Wakeling, A. E., Walker, P. R., and Sikorska, M. (1993) EMBO J. 12, 3679-3684.

24. Susin, S. A., Lorenzo, H. K., Zamzami, N., Marzo, I., Snow, B. E., Brothers, G. M., Mangion, J., Jacotot, E., Costantini, P., Loeffler, M., Larochette, N., Goodlett, D. R., Aebersold, R., Siderovski, D. P., Penninger, J. M., and Kroemer, G. (1999) Nature 397, 441-446.

25. Sahara, S., Aoto, M., Eguchi, Y., Imamoto, N., Yoneda, Y., and Tsujimoto, Y. (1999) Nature 401, 168-173. 
26. Barry, M. A., and Eastman, A. (1993) Arch. Biochem. Biophys. $300,440-450$.

27. Mukae, N., Enari, M., Sakahira, H., Fukuda, Y., Inazawa, J., Toh, H., and Nagata, S. (1998) Proc. Natl. Acad. Sci. U.S.A. 95, 9123-9128.

28. Polzar, B., Zanotti, S., Stephan, H., Rauch, F., Peitsch, M. C., Irmler, M., Tschopp, J., and Mannherz, H. G. (1994) Eur. J. Cell Biol. 64, 200-210.

29. Urbano, A., McCaffrey, R., and Foss, F. (1998) J. Biol. Chem. $273,34820-34827$.

30. Coy, J. F., Velhagen, I., Himmele, R., Delius, H., Poustka, A., and Zentgraf, H. (1996) Cell Death Differ. 3, 199-206.

31. Schulze-Osthoff, K., Krammer, P. H., and Droge, W. (1994) EMBO J. 13, 4587-4596.

32. Parrish, J. E., Ciccodicola, A., Wehhert, M., Cox, G. F., Chen, E., and Nelson, D. L. (1995) Hum. Mol. Genet. 4, 1557-1564.

33. Pergolizzi, R., Appierto, V., Bosetti, A., DeBellis, G. L., Rovida, E., and Biunno, I. (1996) Gene 168, 267-270.
34. Kreuder, V., Dieckhoff, J., Sittig, M., and Mannherz, H. G. (1984) Eur. J. Biochem. 139, 389-400.

35. Rodriguez, A. M., Rodin, D., Nomuram H., Morton, C. C., Weremowicz, S., and Schneider, M. C. (1997) Genomics 42, 507-513.

36. Baron, W. F., Pan, C. Q., Spencer, S. A., Ryan, A. M., Lazarus, R. A., and Baker, K. P. (1998) Gene 215, 291-301.

37. Polzar, B., Peitsch, M. C., Loos, R., Tschopp, J., and Mannherz, H. G. (1993) Eur. J. Cell Biol. 62, 397-405.

38. Zanotti, S., Polzar, B. Stephan, H., Doll, U., Niessing, J., and Mannherz, H. G. (1995) Histochemistry 103, 369-377.

39. Rauch, F., Polzar, B., Stephan, H., Zanotti, S., Paddenberg, R., and Mannherz, H. G. (1997) J. Cell Biol. 137, 909-923.

40. Savio, M., Stivala, L. A., Scovassi, A. I., Bianchi, L., and Prosperi, E. (1996) Oncogene 13, 1591-1598.

41. Van de Klundert, F. A., Gijsen, M. L., van den IJssel, P. R, Snoeckx, L. H., and de Jong, W. W. (1998) Eur. J. Cell Biol. $75,38-45$.

BI000158W 